\title{
The mid-term effects on quality of life and foot functions following pilon fracture
}

\author{
Yüksel Uğur Yaradılmış, M.D.,' 1 Mustafa Caner Okkaoğlu, M.D.,' ${ }^{1}$ Alparslan Kılıç, M.D.,'

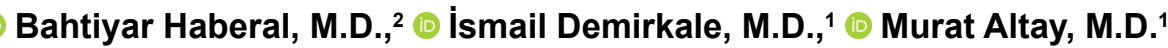

\begin{abstract}
1'Department of Orthopaedics and Traumatology, University of Health Sciences Keçiören Training and Research Center, Ankara-Turkey 2Department of Orthopaedics and Traumatology, Başkent University Faculty of Medicine, Ankara-Turkey
\end{abstract}

\begin{abstract}
BACKGROUND: Although pilon fractures are uncommon, they are of importance to orthopaedic surgeons because of the difficulty of treatment. Poor outcomes and high complication rates are seen despite various surgical methods. This study aims to examine the changes affecting the quality of life and foot functions in patients applied with open reduction and internal fixation (ORIF) for a pilon fracture.

METHODS: In this study, a total of 45 patients treated with ORIF for a pilon fracture in our clinic between January 2010 and December 2016 were evaluated with AOFAS and SF- 12 in a total of 10 categories according to demographic data, fracture classification and surgical technique. In addition to functional values, patient records were examined regarding complications, including infection, soft-tissue defect, malalignment, non-union, arthrosis and Sudeck atrophy. In patients with AOFAS <85 and low SF- 12 scores, variables were examined and the relationship with complications was evaluated.
\end{abstract}

RESULTS: The mean follow-up period was 3.7 years (range 2 to 7 ). The AOFAS value was determined to fall to $<85$ when the Ruedi Allgower classification increased $(p=0.010)$, when AO classification increased $(p=0.020)$, when there was a concomitant lateral malleolar fracture $(p=0.028)$, and when the status was non-anatomic according to the Ovadia Bell criteria $(p=0.03 I)$. The SF- 12 PCS value was observed to decrease when the Ruedi Allgower classification increased $(p=0.018)$ and when the status was non-anatomic according to the Ovadia Bell criteria $(P=0.012)$. A correlation was determined between the SF- 12 PCS and the AOFAS values $(P=0.000)$.

CONCLUSION: The reasons for the failure of ORIF in tibia pilon fractures were found to be Ruedi 3 classification, concomitant lateral malleolar fracture, and non-anatomic surgical reduction. Failure in foot functions has a direct effect on quality of life in both the short and mid term.

Keywords: Arthrosis; infection; open reduction; pilon fracture; quality of life.

\section{INTRODUCTION}

Pilon fractures are fractures of the distal tibia joint surface involving the metaphysis. Some authors have described them as including a $5 \mathrm{~cm}$ section of the distal tibia. ${ }^{[1]}$ Pilon fractures constitute approximately $1 \%$ of all lower extremity fractures and $5 \%-10 \%$ of all tibia fractures. ${ }^{[2]}$ Most pilon fractures occur as a result of a turning or twisting mechanism at varying degrees following axial loading. Although these fractures are seen infrequently, they are labelled as difficult-to-treat frac- tures as they are seen as multi-fragmented articular fractures in a weight-bearing joint. ${ }^{[3,4]}$

The aim of treatment is to obtain anatomic restoration of the joint, appropriate alignment, stable internal fixation and early mobilization. ${ }^{[5,6]}$ Therefore, conservative treatment methods are not currently recommended for these fractures. Open reduction and internal fixation (ORIF), twostage surgery and external fixation methods are used in surgical treatment. Although surgery is the gold standard

Cite this article as: Yaradılmış YU, Okkaoğlu MC, Kılıç A, Haberal B, Demirkale İ, Altay M. The mid-term effects on quality of life and foot functions following pilon fracture. Ulus Travma Acil Cerrahi Derg 2020;26:798-804.

Address for correspondence: Yüksel Uğur Yaradılmış, M.D.

Sağılık Bilimleri Üniversitesi, Keçiören Eğitim ve Araştırma Hastanesi Ortopedi ve Travmatoloji Anabilim Dalı, Ankara, Turkey

Tel: +90 312 - 3569000 E-mail: ugur_yaradilmis@outlook.com 
treatment, low foot function scores and high complication rates may be seen. ${ }^{[7]}$

Another problem encountered in these fractures is low quality of life due to inability to undertake daily tasks and a late return to work. ${ }^{[8,9]}$ Although this study is short-term and presents different surgical techniques, it may be able to provide some ideas for these deficiencies. It is necessary to know the complications of pilon fractures affecting long-term foot functions and quality of life and the effects of these to be able to predict them and take precautions. In this study, an examination was carried out of mid-term foot functions, quality of life and complications occurring in patients applied with ORIF for pilon fractures.

This study aims to investigate the variables affecting foot functions and quality of life in patients applied with ORIF for pilon fracture and to investigate the relationships with complications.

\section{MATERIALS AND METHODS}

A retrospective cohort study examination was carried out with 55 patients who were operated on because of pilon fractures in our clinic between January 2010 and December 2016 (Fig. I). Patients treated with ORIF and followed up for at least two years were included in this study. A total of 10 (18.2\%) patients were excluded from this study: two (3.6\%) patients because external circular fixation was used, two (3.6\%) patients because adjunct foot fractures were treated, and six (10.9\%) patients because of incomplete data. The patients

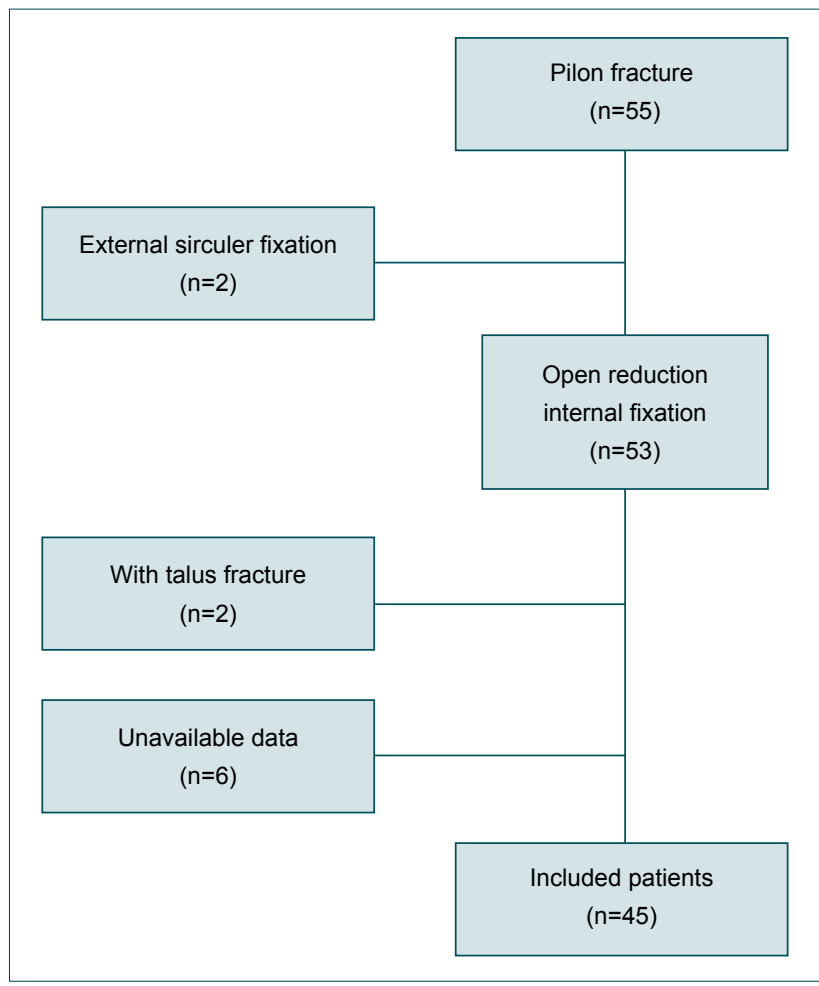

Figure 1. Follow up diagram. were grouped according to age, gender, osteoporosis, preoperative waiting time, postoperative follow-up time, Ruedi Allgower classification, $\mathrm{AO}$ classification, concomitant lateral malleolar fracture, Ovadia Bell criteria, ${ }^{[10]}$ plate placement evaluation and statistical distribution. The 45 (8I.8\%) patients treated with ORIF were evaluated with AOFAS and SF-1 2 according to a total of 10 categories according to demographic data, fracture classification and surgical technique. ${ }^{[1-14]}$ Foot scoring of the patient was made with AOFAS and quality of life was evaluated with the SF-12. The AOFAS values were grouped in four groups as $>85,85-70,70-50$ and $<50$. Apart from the functional values, a record was made for each patient of complications, including infection, soft-tissue defects, malalignment, non-union, arthrosis and Sudeck atrophy.

\section{Preoperative Evaluation}

In the Emergency Department, a splint was applied to the patients, correcting malalignment and providing joint compatibility. Preoperatively, a cold compress, non-steroid anti-inflammatory drugs (NSAID) and antibiotic treatment were applied. Soft tissue was carefully evaluated preoperatively with checks made within the splint three times a day. In cases with a positive "wrinkle test" and the healing of hemorrhagic bullae, surgery was planned with three surgeons' approval. In two of the current series of patients, skeletal traction was applied from the calcaneus as stability was not obtained with the splint (Fig. 2).

\section{Surgical Technique}

Each patient was positioned supine on a radiolucent operating table. A medial or lateral incision was planned according to the fracture wound. In cases with a lateral malleolar fracture, lateral malleolar reduction and fixation were applied first. The joint surface restoration was performed first, then metaphyseal diaphyseal bone reduction. Full joint reduction and $<5^{\circ}$ coronal sagittal, alignment were accepted. When applying medial or lateral plating, an additional fragment-specific screw was applied when necessary (Fig. 3). Soft tissue layers were sutured appropriately.
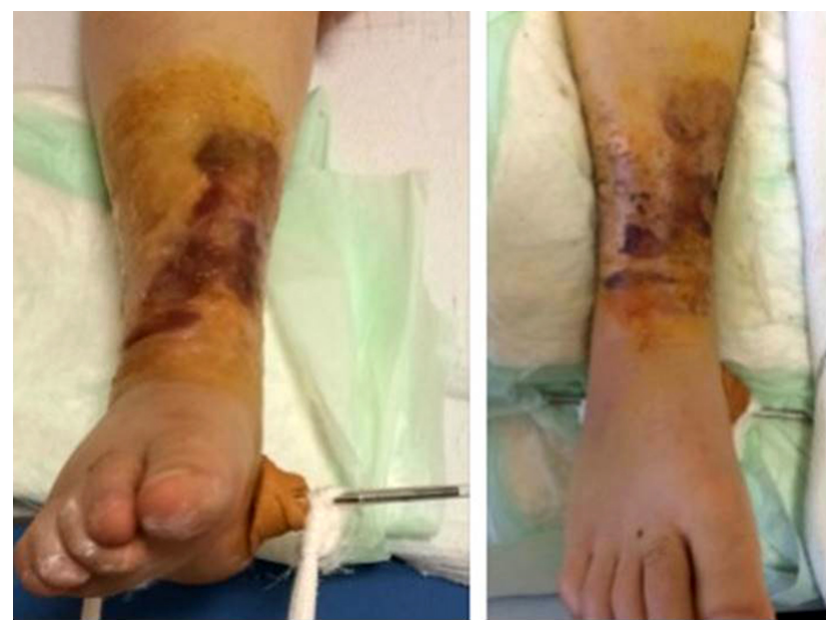

Figure 2. Skeletal traction for instability and follow up soft tissue. 

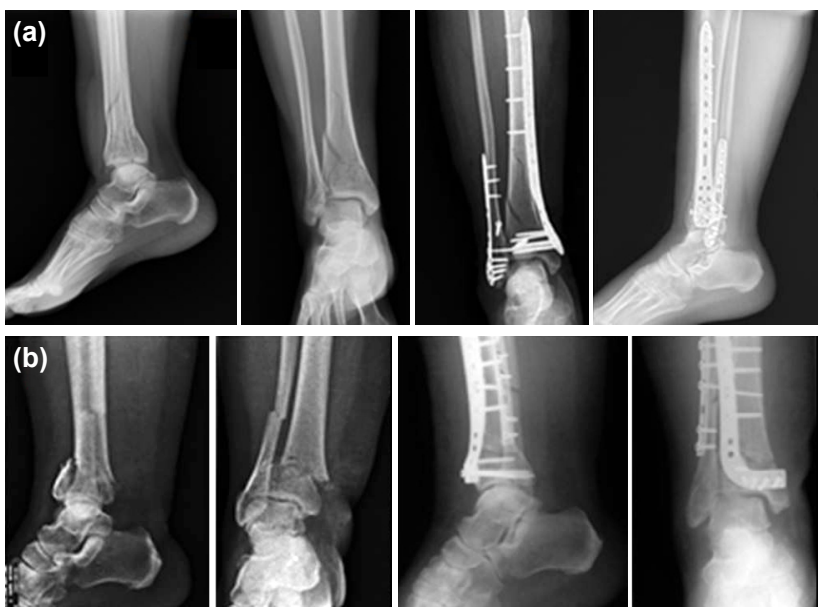

Figure 3. Case example of medial plate fixation (a) and lateral plate fixation (b).

\section{Follow-up}

Soft tissue follow-up was made daily postoperatively, and when it was assured, the patient was discharged. A splint was applied for two weeks for soft tissue healing. At the end of the second week, after removal of the splint, joint range of movement exercises were started together with Vitamin C therapy. Partial weight-bearing was permitted at six weeks postoperatively and full weight-bearing at eight weeks.

\section{Ethical Approval}

Our study was ethically approved by the Ethical Committee of our hospital and also the University of Health Sciences Keçiören Health Practice and Research Center.

\section{Statistical Analysis}

Data obtained in the study were analyzed statistically with SPSS vn 22 software and examined in a $95 \%$ confidence interval. Qualitative data were stated as frequency distribution and quantitative data as mean, minimum and maximum values. The relationships between AOFAS and variables were analyzed using the Chi-square test. To determine differences in SFC-12 PCS (physical) variables, the analysis was applied using ANOVA tests as normal distribution was shown. As the SF-12 MCS (mental) points did not show normal distribution, analyses were applied with the Mann-Whitney and Kruskal Wallis tests. Statistical significance was defined at the $5 \%(p \leq 0.05)$ level.

\section{RESULTS}

The cohort consisted of 29 (64.4\%) males and 16 (35.6\%) female with a mean age of 44.7 years (range 18-77 years). The mean follow-up period was 3.7 years (range 2 to 7 ). The time from trauma to surgery was mean 4.5 days (range $I$ to 16). A preoperative wait of $<7$ days was determined in $70.5 \%$ of cases and $\geq 7$ days in $29.5 \%$. Patient data are shown with frequencies and percentages in Table $I$.
Table I. Demografic data of the patients

\begin{tabular}{|c|c|}
\hline Age, n (\%) & $44.7(18-77)$ \\
\hline$<50$ & $28(62.2)$ \\
\hline$>50$ & $17(37.8)$ \\
\hline \multicolumn{2}{|l|}{ Gender, n (\%) } \\
\hline Male & $29(64.4 \%)$ \\
\hline \multirow[t]{2}{*}{ Female } & $16(35.6 \%)$ \\
\hline & $3.7(I-7)$ \\
\hline \multicolumn{2}{|l|}{ Follow up (year), n (\%) } \\
\hline$<4$ year & $26(57.7)$ \\
\hline \multirow[t]{2}{*}{$>4$ year } & $19(42.3)$ \\
\hline & $4.5(1-16)$ \\
\hline \multicolumn{2}{|l|}{ Preoperatice day, n (\%) } \\
\hline$<7$ day & $31(68.8)$ \\
\hline$>7$ day & $14(31.2)$ \\
\hline \multicolumn{2}{|l|}{ Ruedi allgower, n (\%) } \\
\hline Ruedil & $15(33.3)$ \\
\hline Ruedi2 & $18(40)$ \\
\hline Ruedi3 & $12(26.7)$ \\
\hline $\mathrm{BI}$ & $5(I I . I)$ \\
\hline B2 & II (24.4) \\
\hline B3 & $6(13.3)$ \\
\hline $\mathrm{Cl}$ & $5(11.1)$ \\
\hline $\mathrm{C} 2$ & $7(15.6)$ \\
\hline $\mathrm{C} 3$ & $7(15.6)$ \\
\hline \multicolumn{2}{|c|}{ Ovadia Bells Criteria, n (\%) } \\
\hline Anatomic & $29(64.4)$ \\
\hline Good & $8(17.7)$ \\
\hline Moderate & $7(15.5)$ \\
\hline Poor & I (2.2) \\
\hline \multicolumn{2}{|c|}{ Lateral malleol fracture, $\mathrm{n}(\%)$} \\
\hline Yes & $25(55.5)$ \\
\hline No & $20(44.5)$ \\
\hline \multicolumn{2}{|l|}{ Plate fixation, n (\%) } \\
\hline Medial & $35(77.7)$ \\
\hline Lateral & $10(33.3)$ \\
\hline \multicolumn{2}{|l|}{ AOFAS*, n (\%) } \\
\hline$>85$ & $18(40)$ \\
\hline $70-85$ & $17(37.7)$ \\
\hline $70-50$ & $8(17.7)$ \\
\hline $50-30$ & $2(4.4)$ \\
\hline SFI2-PCS (Physical)* & $47.6(24.2-56.5)$ \\
\hline SFI2-MCS (Mental)* & $59.4(39.9-65.0)$ \\
\hline
\end{tabular}

When patients were grouped acording to AOFAS, $40 \%$ of patients were evaluated as excellent, $37.7 \%$ as good, $17.7 \%$ as fair and $4.4 \%$ as poor. The SF-12 PCS (physical score) was 
mean 47.6 (range, 24.2-56.5) and the SF-I2 MCS (mental) was mean 59.4 (range, 39.9-65.0).

The AOFAS value was determined to fall to $<85$ when the Ruedi Allgower classification increased $(p=0.010)$, when $A O$ classification increased $(B C 1, B C 2, B C 3)(p=0.020)$, when there was a concomitant lateral malleolar fracture $(p=0.028)$, and when the status was non-anatomic according to the Ovadia Bell criteria $(p=0.031)$ (Table 2).

Arthrosis was observed in II patients (24\%) and in these II, a significant difference was observed from other patients in re-

Table 2. Analysis of the relationship between AOFAS and variables

\begin{tabular}{|c|c|c|c|}
\hline & \multicolumn{2}{|c|}{ AOFAS } & \multirow[t]{2}{*}{$\mathbf{p}$} \\
\hline & $>85$ & $<85$ & \\
\hline \multicolumn{4}{|l|}{ Age, $n(\%)$} \\
\hline$<50$ & $10(37)$ & $17(63)$ & 0.784 \\
\hline$>50$ & $7(4 \mid .2)$ & $10(58.8)$ & \\
\hline \multicolumn{4}{|l|}{ Gender, n (\%) } \\
\hline Male & $8(28.6)$ & $20(7 \mid .4)$ & 0.068 \\
\hline Female & $9(56.3)$ & $7(43.8)$ & \\
\hline \multicolumn{4}{|c|}{ Follow up (year), n (\%) } \\
\hline$<4$ year & $12(46.2)$ & $14(53.8)$ & 0.436 \\
\hline$>4$ year & $5(29.4)$ & $12(70.6)$ & \\
\hline \multicolumn{4}{|c|}{ Preoperative day, n (\%) } \\
\hline$<7$ day & $13(4 \mid .9)$ & I8 (58.1) & 0.437 \\
\hline$>7$ day & $4(33.3)$ & $8(66.7)$ & \\
\hline \multicolumn{4}{|c|}{ Ruedi allgower, n (\%) } \\
\hline Ruedil & $10(66.7)$ & $5(33.3)$ & $0.010^{*}$ \\
\hline Ruedi2 & $6(33.3)$ & $12(66.7)$ & \\
\hline Ruedi3 & I (9.1) & $10(90.9)$ & \\
\hline \multicolumn{4}{|c|}{ AO clasification, n (\%) } \\
\hline $\mathrm{BI}-\mathrm{Cl}$ & $7(70)$ & $3(30)$ & $0.020^{*}$ \\
\hline B2-C2 & $6(33.3)$ & $12(66.7)$ & \\
\hline B3-C3 & I (8.3) & II (9I.7) & \\
\hline \multicolumn{4}{|c|}{ Intact fibula, n (\%) } \\
\hline No & II (57.9) & $8(42.1)$ & $0.028^{*}$ \\
\hline Yes & $6(25)$ & $18(75)$ & \\
\hline \multicolumn{4}{|c|}{ Ovadia Bells Criteria, n (\%) } \\
\hline Anatomic & $15(5 \mathrm{I} .7)$ & $14(48.3)$ & $0.031^{*}$ \\
\hline Other & $2(13.3)$ & $13(86.7)$ & \\
\hline \multicolumn{4}{|c|}{ Plate fixation, n (\%) } \\
\hline Medial & $15(42.9)$ & $20(57.1)$ & 0.304 \\
\hline Lateral & $2(25)$ & $6(75)$ & \\
\hline
\end{tabular}

${ }^{*} \mathrm{p}<0.05$. AOFS: American Orthopedic Foot and Ankle Society. spect of SF- I 2 values $(p=0.04 I)$. Arthodesis was not requested as treatment in any of the patients with arthrosis (Table 3).

Table 3. Analyse of the relationship between SFI2-PCS and variables

\begin{tabular}{|c|c|c|}
\hline & SFI2-PCS (Physical) & $\mathbf{p}$ \\
\hline \multicolumn{3}{|l|}{ Age } \\
\hline$<50$ & $48.08 \pm 6.59$ & 0.593 \\
\hline$>50$ & $46.82 \pm 9.04$ & \\
\hline \multicolumn{3}{|l|}{ Gender } \\
\hline Male & $47.15 \pm 6.22$ & 0.640 \\
\hline Female & $48.42 \pm 9.65$ & \\
\hline \multicolumn{3}{|l|}{ Follow up (year) } \\
\hline$<4$ year & $47.5 \pm 8.51$ & 0.907 \\
\hline$>4$ year & $47.78 \pm 6.35$ & \\
\hline \multicolumn{3}{|c|}{ Preoperaative time (day) } \\
\hline$<7$ day & $48.52 \pm 6.71$ & 0.229 \\
\hline$>7$ day & $45.46 \pm 9.41$ & \\
\hline \multicolumn{3}{|l|}{ Ruedi Allgower } \\
\hline Ruedil & $51.59 \pm 5.16$ & $0.018^{*}$ \\
\hline Ruedi2 & $46.89 \pm 7.01$ & \\
\hline Ruedi3 & $43.68 \pm 8.82$ & \\
\hline \multicolumn{3}{|l|}{ Intact fibula } \\
\hline Yes & $49.63 \pm 6.01$ & 0.119 \\
\hline No & $46 \pm 8.43$ & \\
\hline \multicolumn{3}{|l|}{ Ovadia Bells Criteria } \\
\hline Anatomic & $49.81 \pm 6.45$ & $0.012 *$ \\
\hline Good & $41.43 \pm 9.75$ & \\
\hline Moderate/poor & $45.78 \pm 5.3$ & \\
\hline \multicolumn{3}{|l|}{ Plate fixatio } \\
\hline Medial & $47.95 \pm 6.94$ & 0.765 \\
\hline Lateral & $47.58 \pm 6.78$ & \\
\hline $\mathrm{BI}-\mathrm{Cl}$ & $50.84 \pm 5.45$ & \\
\hline \multicolumn{3}{|l|}{ AO clasification } \\
\hline B2-C2 & $47.22 \pm 6.86$ & 0.059 \\
\hline B3-C3 & $43.47 \pm 8.47$ & \\
\hline \multicolumn{3}{|l|}{ AOFAS } \\
\hline$>85$ & $53.94 \pm 3.83$ & $0.000^{*}$ \\
\hline $70-85$ & $46.82 \pm 4.42$ & \\
\hline$<70$ & $38.75 \pm 6.96$ & \\
\hline \multicolumn{3}{|l|}{ Infection } \\
\hline Superfisial/deep & $40.20 \pm 4.29$ & \\
\hline No & $49.26 \pm 7.23$ & $0.002^{*}$ \\
\hline \multicolumn{3}{|l|}{ Artrosis } \\
\hline Yes & $43.92 \pm 6.56$ & \\
\hline No & $48.79 \pm 7.53$ & $0.04 I^{*}$ \\
\hline
\end{tabular}

${ }^{*} \mathrm{p}<0.05$. AOFS: American Orthopedic Foot and Ankle Society. 
Infection was observed in eight patients (17\%), all of whom sustained the fracture in high-energy trauma (Ruedi 2: $n=2$, Ruedi 3: $n=6$ ). Patients with superficial infection were treated with oral antibiotics and for those with deep infection, the implant was removed and debridement was treated. Delayed union was observed in one of the patients with deep infection. Arthrosis developed in three patients with superficial infection and in one with deep infection. A significant difference was determined between the patients with infection and the other patients regarding the long-term scores $(p=0.002)$.

Sudeck's atrophy was observed in four patients (9\%), of whom three patients had C3 fractures and one patient had a C2 fracture. Treatment was applied with a physical therapy program.

Malalignment was observed in five patients ( $11 \%)$, all of whom had a concomitant lateral malleolar fracture.

Full union of the fractures was obtained at a high rate (95.5\%). In two patients with delayed union, one patient had a B2 fracture with deep infection and the other patient had a $\mathrm{Cl}$ fracture with superficial infection.

\section{DISCUSSION}

Pilon fractures are always accepted as problematic fractures by orthopaedic surgeons because they are injuries of large dimensions with damage to the cartilage joint surface and soft tissue oedema. ${ }^{[15]}$ High complication rates are seen, which may include skin necrosis and infection in the early period, and non-union and arthrosis in the long-term. ${ }^{[16-19]}$ However, they are infrequently seen fractures constituting approximately I\% of all lower extremity fracture. ${ }^{[2]}$

In the current study, the severity of the injury was determined as Ruedi I in 33.3\%, Ruedi 2 in $40.0 \%$ and Ruedi 3 in $26.7 \%$. There were seen to be similar rates of low-energy and high-energy traumas.

The time from trauma to surgery was mean 4.5 days (range, $1-16$ days) and this period was seen to be prolonged in cases evaluated as Ruedi 3. The approach of early surgery before soft tissue swelling has formed has been abandoned as some studies have reported worse results from surgery performed in the first five days. ${ }^{[20]}$ This period varies according to the severity of the injury. When the soft tissue status has been ensured, surgery should be applied.

Successful operations with ORIF came to prominence with a study by Rüedi and Allgöwer ${ }^{[21]}$ in 1969, which reported $74 \%$ success in 84 patients treated with ORIF. Anatomic reduction according to $\mathrm{AO}$ rules and early mobilization were applied. The weakest point of that study was that the majority of patients had low-energy skiing injuries. In a second series by the same team, the majority of cases arose from by high-energy injuries (traffic accidents). The same level of success could not be achieved with a good result obtained in $69 \%$. Other studies conducted according to the mechanism of injury have reported that the success rate has fallen to $50 \% .{ }^{[22]}$

When the patients in the current study were grouped acording to AOFAS, $40 \%$ of the patients were evaluated as excellent, $37.7 \%$ as good, $17.7 \%$ as fair and $4.4 \%$ as poor. Rubio-Suarez et al. ${ }^{[19]}$ treated 90 patients with ORIF and reported $30.5 \%$ as excellent results (>85 AOFAS), $46.7 \%$ as good, $13.1 \%$ as fair and $9.7 \%$ as poor. In that study, Rubio-Suarez et al. ${ }^{[19]}$ examined complications and emphasized the risk of medial plating.

When the patients with AOFAS <85 (60\%) were examined in the current study, they were seen to be those with Ruedi type $3(p=0.010)$ and AO type $C$ injuries $(p=0.020)$, those with lateral malleolar fractures $(p=0.028)$ and those who were non-anatomic according to Ovadia Bell criteria $(p=0.03 \mathrm{I})$. No difference was seen regarding age, gender, preoperative waiting time, follow-up period, and plate placement. Infection and arthrosis were determined to decrease AOFAS values.

Ilizarov fixation was applied to two patients because of both metaphyseal and tibial defect, and these cases were excluded from this study. Single-stage ORIF was applied to the pilon fractures externally. Rather than two-stage surgery the cases were transferred to the ward with a splint. In two patients (4.4\%) where stability could not be achieved with a splint, skeletal traction was applied from the calcaneus and they were followed up in the ward.

When the single-stage ORIF of the current study was compared with literature, the results of single-stage were found to be the same as those for two-stage. ${ }^{[23]}$ In a similar study that compared three methods, low AOFAS scores were obtained with external fixators. ${ }^{[24]}$ However, the use of external fixators in more severe injuries could explain the worse results of external fixators in these studies. In a comparison of limited ORIF and external fixation with ORIF, no shortfall was found in the limited approach. ${ }^{[25]}$ In Ruedi Allgower type $I$ and type 2 injuries, results have been shown to be better irrespective of the treatment, and treatment problems have not yet been resolved in Ruedi type 3 injuries. ${ }^{[26]}$ In the light of these data, the effects of classic ORIF treatment were examined in the current study rather than the surgical methods.

The SF-12 PCS value in the current study was found to be mean 47.6 (range, 24.2-56.5), which was lower than the SF- I 2 value of the Turkish population in general. However, the SFI 2 MCS value of mean 59.4 (range, 39.9-65.0) was observed to be similar to that of the general population. When the SF12 PCS was examined, the most significant relationship was seen to be in parallel with the AOFAS values $(p=0.000)$. Cutillas-Ybarra et al. ${ }^{\left[{ }^{[9]}\right.}$ examined short-term quality of life with the SF36 and reported that patients were affected both physically and psychosocially compared to the general population. In 
the current study, foot function in the long-term was found to have no mental effect (SF-I 2 MCS evaluation). The SF-I 2 PCS was seen to be most affected by foot functions. In a similar study in Australia of a 12-month examination of pilon fractures, lower SF-I2 PCS values were obtained. ${ }^{[8]}$

A concomitant lateral malleolar fracture was observed to reduce the functional results in the current study $(p=0.028)$. In a study by Liangjun et al., ${ }^{[2]}$ higher functional results were obtained in pilon fractures with an intact lateral malleolus.

Medial plate placement has been said to be associated with skin necrosis, more severe arthrosis and non-union.7 In the current study, flap was applied to one patient with medial plate placement. In addition, of the eight patients who developed infection, there was observed to be medial plate osteosynthesis in seven patients. However, no difference was determined regarding arthrosis and non-union. Although there was no statistically significant difference, there was observed to be more arthrosis in cases with lateral plate placement (lateral plate osteosynthesis $44.4 \%$, medial plate osteosynthesis $20 \%$ ).

In a study by Rubio-Suarez et al., ${ }^{[19]}$ ORIF complications were examined in a series of 137 patients. Skin necrosis was determined in $15 \%$, non-union in $16 \%$, arthrosis in $13 \%$ and infection in $8 \%$.

In the current study, infection was observed at the rate of $17.7 \%$. In two (4\%) patients with deep infection, the implant was removed and debridement was performed, and the only risk factor was determined to be Ruedi classification $(p=0.044)$. As the severity of the wound increases, care must be taken in respect of infection. Delayed union was seen in two $(4.4 \%)$ patients. The two patients with non-union were also determined to have infection (I superficial, I deep).

Arthrosis was observed in II (24.4\%) patients of the current study. In Ruedi type 3, AO type C injuries, patients with concomitant lateral malleolar fracture $(p=0.028)$ and those with non-anatomic fixation according to Ovadia Bell $(p=0.031)$, arthrosis was observed at a statistically signifcantly higher rate. Patients with arthrosis were seen to have lower AOFAS and SF-I 2 scores. Arthrodesis was not requested for any of these patients. Similarly, Bonar et al. ${ }^{[28]}$ reported that arthodesis was not required in patients with reduction and malalignment.

\section{Conclusion}

The results of this study demonstrated that the reasons for ORIF failure in tibia pilon fractures were Ruedi 3, lateral malleolar fracture, and non-anatomic reduction. Failure in foot functions has a direct effect on the quality of life in both the short and mid-term.

Ethics Committee Approval: Approved by the local ethics committee.
Peer-review: Internally peer-reviewed.

Authorship Contributions: Concept: Y.U.Y; Design: Y.U.Y., B.H.; Supervision: Y.U.Y, B.H.; Fundings: Y.U.Y., A.K.; Materials: Y.U.Y., A.K.; Data: Y.U.Y., A.K.; Analysis: Y.U.Y., I.D; Literature search: Y.U.Y., M.C.O; Writing: Y.U.Y., M.C.O.; Critical revision: Y.U.Y., M.A.

Conflict of Interest: None declared.

Financial Disclosure: The authors declared that this study has received no financial support.

\section{REFERENCES}

1. Tornetta P 3rd, Weiner L, Bergman M, Watnik N, Steuer J, Kelley M, et al. Pilon fractures: treatment with combined internal and external fixation. J Orthop Trauma 1993;7:489-96. [CrossRef]

2. Bourne RB, Rorabeck $\mathrm{CH}, \mathrm{Macnab}$ J. Intra-articular fractures of the distal tibia: the pilon fracture. J Trauma 1983;23:591-6. [CrossRef]

3. Chowdhry M, Porter K. The pilon fracture. Trauma 2010;12:89-103.

4. Calhoun JH, Li F, Ledbetter BR, Viegas SF. A comprehensive study of pressure distribution in the ankle joint with inversion and eversion. Foot Ankle Int 1994;15:125-33. [CrossRef]

5. Borrelli J Jr, Ellis E. Pilon fractures: assessment and treatment. Orthop Clin North Am 2002;33:231-x. [CrossRef]

6. Rüedi T. Fractures of the lower end of the tibia into the ankle joint: results 9 years after open reduction and internal fixation. Injury 1973;5:130-4.

7. Carbonell-Escobar R, Rubio-Suarez JC, Ibarzabal-Gil A, RodriguezMerchan EC. Analysis of the variables affecting outcome in fractures of the tibial pilon treated by open reduction and internal fixation. J Clin Orthop Trauma 2017;8:332-8. [CrossRef]

8. Bonato LJ, Edwards ER, Gosling CM, Hau R, Hofstee DJ, Shuen A, et al. Patient reported health related quality of life early outcomes at 12 months after surgically managed tibial plafond fracture. Injury 2017;48:946-53.

9. Cutillas-Ybarra MB, Lizaur-Utrilla A, Lopez-Prats FA. Prognostic factors of health-related quality of life in patients after tibial plafond fracture. A pilot study. Injury 2015;46:2253-7. [CrossRef]

10. Ovadia DN, Beals RK. Fractures of the tibial plafond. J Bone Joint Surg Am 1986;68:543-51. [CrossRef]

11. Kitaoka HB, Alexander IJ, Adelaar RS, Nunley JA, Myerson MS, Sanders M. Clinical rating systems for the ankle-hindfoot, midfoot, hallux, and lesser toes. Foot Ankle Int 1994;15:349-53. [CrossRef]

12. Ibrahim T, Beiri A, Azzabi M, Best AJ, Taylor GJ, Menon DK. Reliability and validity of the subjective component of the American Orthopaedic Foot and Ankle Society clinical rating scales. J Foot Ankle Surg 2007;46:65-74.

13. Ware J Jr, Kosinski M, Keller SD. A 12-Item Short-Form Health Survey: construction of scales and preliminary tests of reliability and validity. Med Care 1996;34:220-33.

14. Orthotolkit. SF-12 - OrthoToolKit. Available at: http://orthotoolkit. $\mathrm{com} / \mathrm{sf}-12$.

15. Mast JW, Spiegel PG, Pappas JN. Fractures of the tibial pilon. Clin Orthop Relat Res 1988;230:68-82. [CrossRef]

16. McFerran MA, Smith SW, Boulas HJ, Schwartz HS. Complications encountered in the treatment of pilon fractures. J Orthop Trauma 1992;6:195-200. [CrossRef]

17. D’Alleyrand JC, Manson TT, Dancy L, Castillo RC, Bertumen JB, Meskey $T$, et al. Is time to flap coverage of open tibial fractures an independent predictor of flap-related complications?. J Orthop Trauma 2014;28:288-93. [CrossRef] 
18. Lomax A, Singh A, N Jane M, C Senthil K. Complications and early results after operative fixation of 68 pilon fractures of the distal tibia. Scott Med J 2015;60:79-84. [CrossRef]

19. Rubio-Suarez JC, Carbonell-Escobar R, Rodriguez-Merchan EC, Ibarzabal-Gil A, Gil-Garay E. Fractures of the tibial pilon treated by open reduction and internal fixation (locking compression plateless invasive stabilising system): Complications and sequelae. Injury 2018;49:S60-4. [CrossRef]

20. Trumble TE, Benirschke SK, Vedder NB. Use of radial forearm flaps to treat complications of closed pilon fractures. J Orthop Trauma 1992;6:358-65. [CrossRef]

21. Rüedi TP, Allgöwer M. The operative treatment of intra-articular fractures of the lower end of the tibia. Clin Orthop Relat Res 1979;(138):105-10.

22. Kellam JF, Waddell JP. Fractures of the distal tibial metaphysis with intra-articular extension--the distal tibial explosion fracture. J Trauma 1979;19:593-601. [CrossRef]

23. Minator Sajjadi M, Ebrahimpour A, Okhovatpour MA, Karimi A, Zandi R, Sharifzadeh A. The Outcomes of Pilon Fracture Treatment: Prima- ry Open Reduction and Internal Fixation Versus Two-stage Approach. Arch Bone Jt Surg 2018;6:412-9.

24. Biz C, Angelini A, Zamperetti M, Marzotto F, Sperotto SP, Carniel D, et al. Medium-Long-Term Radiographic and Clinical Outcomes after Surgical Treatment of Intra-Articular Tibial Pilon Fractures by Three Different Techniques. Biomed Res Int 2018;2018:6054021. [CrossRef]

25. Zhang SB, Zhang YB, Wang SH, Zhang H, Liu P, Zhang W, et al. Clinical efficacy and safety of limited internal fixation combined with external fixation for Pilon fracture: A systematic review and meta-analysis. Chin J Traumatol 2017;20:94-8. [CrossRef]

26. Kemal Aktuğlu, Nadir Özkayın. Surgical modalities in tibial pilon fractures TOTBID Derg 2013;12:142-52. [CrossRef]

27. Liangjun J, Qiang Z, Hang L, Zhijun P. Injury mechanism, fracture characteristics and clinical treatment of pilon fracture with intact fibula-A retrospective study of 23 pilon fractures. J Clin Orthop Trauma 2017;8:S9-15. [CrossRef]

28. Bonar SK, Marsh JL. Tibial Plafond Fractures: Changing Principles of Treatment. J Am Acad Orthop Surg 1994;2:297-305. [CrossRef]

\section{ORİIINAL ÇALIŞMA - ÖZET}

\section{Pilon kırıkları sonrası ayak fonksiyonları ve hayat kalitesinde orta dönem etkenler \\ Dr. Yüksel Uğur Yaradılmış, ${ }^{1}$ Dr. Mustafa Caner Okkaoğlu, ${ }^{1}$ Dr. Alparslan Kılıç, \\ Dr. Bahtiyar Haberal, ${ }^{2}$ Dr. İsmail Demirkale, ${ }^{1}$ Dr. Murat Altay ${ }^{1}$}

'Sağlık Bilimleri Üniversitesi, Keçiören Eğitim ve Araştırma Hastanesi, Ortopedi ve Travmatoloji Anabilim Dalı, Ankara ${ }^{2}$ Başkent Üniversitesi Tıp Fakültesi, Ortopedi ve Travmatoloji Anabilim Dalı, Ankara

AMAÇ: Pilon kırıkları az görülmesine rağmen tedavisi zor olması nedeniyle ortopedik cerrahlar tarafından önemsenmiştir. Değişen cerrahi yöntemlere rağmen kötü sonuç ve yüksek komplikasyonlar görülmektedir. Bu çalışmanın amacı, pilon kırı̆̆ı nedeniyle açık redüksiyon ve iç fiksasyon (ORIF) yaptığımız hastalarda ayak fonksiyonları ve hayat kalitesini etkileyen değişkenleri incelemek ve komplikasyonlarla ilişkilendirmek.

GEREÇ VE YÖNTEM: Kliniğimizde Ocak 2010 -Aralık 2016 tarihleri arasında, pilon kırığı nedeniyle ORIF uygulanan 45 hasta demografik verileri, kırık sınıflaması ve cerrahi tekniğe göre toplam 10 kategoriye göre AOFAS ve SF-12 ile değerlendirildi. Hastalar fonksiyonel değerler haricinde komplikasyonlar olarak enfeksiyon, yumuşak doku defekti, dizilim bozukluğu, kaynamama, artroz ve Sudeck atrofisi açısından da hastaların kayıtları incelendi. AOFAS 85 altı olan ve düşük SFI 2 olan hastaların değişkenleri incelendi ve komplikasyonlarla ilişkisi değerlendirildi.

BULGULAR: Ortalama takip süresi 3.7 yıl olup (2-7 yıl). AOFAS değerlerine bakıldığında, Ruedi-Allgower sınıflaması arttığında $(p=0.010), A O$ sınıflaması arttığında $(p=0.020)$, eşlik eden lateral malleol kırı̆ı̆ında $(p=0.028)$ ve Ovadia-Bell kriterleri'ne göre non-anatomik olması durumunda $(p=0.03 \mathrm{I})$ AOFAS değerleri 85 'in altına düşmektedir. SF-12 PCS değerlerine bakıldığında, Ruedi-Allgower sınıflaması arttığında $(p=0.018)$, OvadiaBell kriterleri'ne göre non-anatomik olması durumunda $(p=0.012)$ SF- 12 PCS değerlerinde düşme gözlendi. SF-I2 PCS ile AOFAS değerlerinde korelasyon gözlendi $(p=0.000)$.

TARTIŞMA: Tibia pilon kırıklarında ORIF ile başarısızık nedeni Ruedi 3, lateral malleol kırığı, cerrahi anatomik olmayan redüksiyon olarak bulundu. Ayak fonksiyonlarındaki başarısızlık hem erken dönem hem de orta dönemde hayat kalitesini doğrudan etkilemektedir.

Anahtar sözcükler: Açık cerrahi; artroz, enfeksiyon; hayat kalitesi; pilon kırıkları.

Ulus Travma Acil Cerrahi Derg 2020;26(5):798-804 doi: 10.14744/tjtes.2020.8560 I 